\title{
Characterization of Antimicrobial Resistance and Virulence Profile of Vibrio Parahaemolyticus in Water and Bivalve Mollusck Samples
}

Norma Suely Evangelista-Barreto (I), Irana Paim Silva (I), Carla da Silva Silveira (I), Leopoldo Melo Barreto (I), Oscarina Viana de Sousa (II)

(I) UFRB - Universidade Federal do Recôncavo da Bahia (Rua Rui Barbosa, 710, Centro, Cruz das Almas, Bahia. CEP: 44380-000), (II) UFC/LABOMAR - Universidade Federal do Ceará (Av. Abolição, 3207, Meireles, Fortaleza, Ceará, CEP: 60165-081)

\section{Resumo}

The objective of the present study was to characterize the antimicrobial susceptibility profile and virulence factors of Vibrio parahaemolyticus in water and bivalve mollusck samples in the estuary of the river São Francisco do Conde, Bahia, Brazil. Every month for 15 months collections were made of estuary water (45 samples), oysters and mussels (30 in natura and 15 processed samples). The strains were identified biochemically according to the identification key for environmental strains. The antimicrobial susceptibility tests were carried out with 11 pharmacons from seven families, the minimum inhibitory concentration (MIC) and metallo$\beta$-lactamase (M $\beta \mathrm{Ls}$ ) enzyme production. To characterize virulence, exoenzyme production was used (amylase, caseinase, DNase, phospholipase, gelatinase, lipase and urease), hemolytic activity and the tdh and trh primers. Ten species were identified and 67\% (30/45) belonged to V. parahaemolyticus (38\% in water, $18 \%$, in natura bivalve molluscks and $11 \%$ processed mussel). Antimicrobial resistance was observed of at least one of the 11 antimicrobials tested, with a high percentage for ampicillin $(97 \%)(55 \%$ in water isolates, $27 \%$ in in natura bivalve molluscks and $17 \%$ in processed mussel) and $400 \mu \mathrm{g}$ MIC and cephalothin (93\%) (53\% in water isolates, $28 \%$ in in natura bivalve molluscks and $18 \%$ in processed mussel) and $\leq 100 \mu \mathrm{g}$ MIC. Multi-resistance was observed in 59\% of the 
water strains, $75 \%$ of the in natura bivalve molluscks and in $20 \%$ of the processed mussel. All the isolates produced the MßLs enzyme. For the phenotypic virulence profile the highest positivity percentage was for amylase (97\%), DNase (83\%), phospholipase (70\%), $\beta$-hemólise (57\%), gelatinase (43\%), lipase (13\%) and caseinase (7\%). The tdh and trh virulence genes were not detected. Environmental strains are generally difficult to characterize because they live in an environment with intense variations and can insert or exclude traits. The high microbial resistance and $\mathrm{M} \beta \mathrm{L}$ s production in $\mathrm{V}$. parahaemolyticus showed that the environment under study has undergone human pressure. Although expression of the tdh and trh virulence genes was not verified, the high production of exoenzymes facilitates host tissue invasion and lesion by the microorganism and there is also toxigenic potential.

Palavras-Chave: antimicrobial susceptibility, metallo- $\beta$-lactamase , virulence, mussels

\section{Agência de Fomento:}

